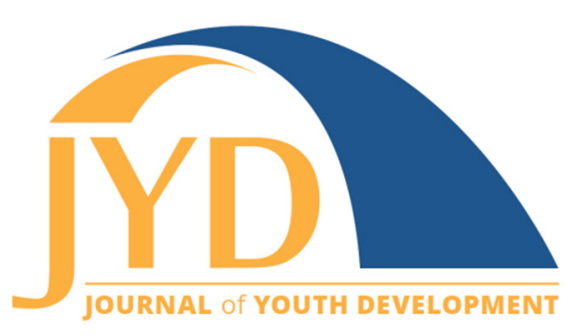

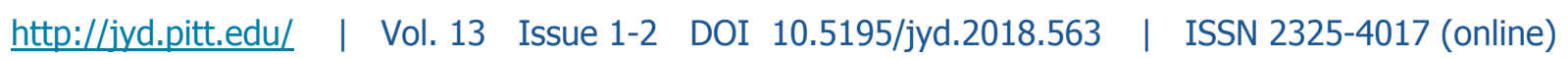

\title{
Examining the Role of Summer Camps in Developing Academic and Workplace Readiness
}

\author{
Cait Wilson \\ University of Utah \\ cait.wilson@utah.edu \\ Jim Sibthorp \\ University of Utah \\ jim.sibthorp@health.utah.edu
}

\begin{abstract}
Summer camps are an effective setting for youth to develop skills essential for academics and the workplace yet are often not recognized as such. Therefore, the primary aim of this study was to investigate learning outcomes from camp most applicable to academics and workplace readiness. As a secondary aim, the researchers sought to identify the mechanisms at camp that support this learning. Youths' primary learning outcomes include relationship skills, teamwork, how to live with peers, selfconfidence, organization, responsibility, independence, perseverance, career orientation, and emotion regulation. In general, mechanisms that supported participants'learning of outcomes included experiential learning, camp as separate time and space, camp schedules, the role of counselors, communal living, safe and supportive environments, and diversity of people. The implications for camp staff include furthering their programming efforts by placing an emphasis on the mechanisms that elicit academic and workplace readiness. With intentional effort, summer camp can be an important setting for youth to learn valuable skills that are beneficial for them to succeed in academics and work.
\end{abstract}

Key words: $21^{\text {st }}$ century skills, experiential learning, learning transfer, workplace readiness

\section{Introduction}

In today's knowledge-based society, there is an increased demand for individuals who are prepared to succeed in academics and the workplace. Academic readiness refers to an individual who is academically prepared in reading, writing, and mathematics knowledge and possesses life skills (e.g. interpersonal skills and leadership) necessary in an academic environment (NAEP, 2013). Workplace readiness refers to a worker who has basic academic

\footnotetext{
(cc) EY New articles in this journal are licensed under a Creative Commons Attribution 4.0 License. This journal is published by the University Library System, University of Pittsburgh and is cosponsored by the University of Pittsburgh Press. The Journal of Youth Development is the official peer-reviewed publication of the National Association of Extension 4-H Agents and the National AfterSchool Association.
} 
preparation and the life skills needed to maintain employment (McClarty, Mattern, \& Gaertner, 2017). While we realize many other ways exist to prepare youth for life, in this paper we have chosen to focus on skills that most closely align with preparation for academics and the workplace.

\section{A Framework on Academic and Workplace Readiness}

The National Research Council offers a robust and holistic framework on a variety of skills that prepare an individual for academics and the workplace (National Research Council, 2012). The benefits for young people who are adequately prepared for academics and work are clear; they are more likely to succeed in coursework and have higher employment rates and wages upon graduation (Sambolt \& Blumenthal, 2013). Table 1 outlines clusters of skills that support success in academics and the workplace (National Research Council, 2012).

Table 1. Skill Clusters for Academic and Workplace Readiness ${ }^{1}$ (adapted from National Research Council, 2012)

\begin{tabular}{|l|l|}
\hline Skill cluster & Examples \\
\hline Cognitive processes and strategies & Critical thinking, problem solving, decision making \\
\hline Knowledge & $\begin{array}{l}\text { Oral and written communication, active listening, } \\
\text { information literacy }\end{array}$ \\
\hline Creativity & Innovation \\
\hline Intellectual openness & Appreciation for diversity, flexibility, adaptability \\
\hline Work ethic and conscientiousness & $\begin{array}{l}\text { Responsibility, perseverance, work ethic, career } \\
\text { orientation }\end{array}$ \\
\hline Positive core self-evaluation & Self-confidence, self-identity, emotion regulation \\
\hline Teamwork and collaboration & Interpersonal skills, teamwork, empathy, compassion \\
\hline Leadership & Social influence with others \\
\hline
\end{tabular}

Note: The skills identified were not hypothesized to be equally targeted by and attributed to summer camps.

\footnotetext{
${ }^{1}$ While these skills are largely aligned with college and career readiness, we are using the terms academic and workplace readiness, since our study participants were not through college and did not yet have established careers.
} 


\section{Role of Camps in Academic and Workplace Readiness}

\section{Addressing the Skills Gap}

Widespread concern exists that young people in the United States lack essential skills (CasnerLotto \& Barrington, 2006). Only one in four high school seniors are ready for college (Venezia \& Jaeger, 2013), and about 31 percent of employers are struggling to fill available positions because workers do not have the specific skill sets employers need (Manpower, 2010). As a result, private foundations, policymakers, and education organizations are attempting to remedy this skills gap by increasing ways for youth to develop the robust suite of skills necessary to succeed in academics, work, and life. Youth programs are one viable option to help youngsters develop these essential skills but have yet to be realized as a key resource (Cochran \& Ferrari, 2009).

One type of youth program that provides opportunities to develop important skills employers value, such as interpersonal skills and teamwork, is summer camp (e.g., Collins, 2006; Thurber, Scanlin, Schueler, \& Henderson, 2007). There is an abundance of short-term outcomes studies (e.g., American Camp Association, 2005), yet few studies have investigated the learning most pertinent to academic and workplace readiness long after programs end.

Of additional interest to researchers are the mechanisms at camp that contribute to outcomes applicable to academics and work. Garst, Browne, and Bialeschki (2011) identified a variety of mechanisms in camp programs that may be influential on camper learning outcomes such as structure (e.g., duration), setting (e.g., being away), program/activity features (e.g., experiential learning), and staff (e.g., counselors). However, research on the mechanisms at camp that lead to the development of youth outcomes is underexamined (Yohalem \& WilsonAhlstrom, 2010). Evidence on the mechanisms likely to influence academic and workplace readiness learning outcomes is necessary so camp providers can increase intentional programming efforts (Garst, 2010).

\section{Purpose of the Study}

This study is the first phase of a 5-year, three-phase research project examining the impacts of camp on youth. This initial phase was conducted to identify the most promising learning outcomes from camp useful in daily life (i.e., academic and workplace settings). The second phase will quantitatively measure the learning outcomes most distinctly learned at camp and useful in everyday life amongst a representative, national sample. The third phase of the 
Journal of Youth Development | http://jyd.pitt.edu/ | Vol. 13 Issue 1-2 DOI 10.5195/jyd.2018.563

Role of Camps in Academic and Workplace Readiness

project will then longitudinally track the identified learning outcomes among campers over 3 years. This article reports on the first phase of this larger project.

The purpose of this phase of the larger study was to investigate campers' long-term learning outcomes from camp that are applicable to academic and workplace readiness. The study sought to answer the following research questions:

1. What outcomes do former campers report learning during their times at camp that relate to academic and workplace readiness?

2. What mechanisms at camp made these learning outcomes possible?

\section{Methods}

This study employed an inductive qualitative approach to identify the most transferable learning outcomes related to academic and workplace readiness. Data collection involved structured interviews with former campers. The inclusion criteria for the sample included those young people who attended a camp based in the United States for at least 3 weeks as a child and had no previous employment at camp. These interviews were then transcribed, coded, and analyzed for emergent themes.

\section{Sample}

The sampling strategy targeted newly hired camp staff who had not yet started working at their camp jobs through an intentionally stratified selection of 22 camps accredited by the American Camp Association (ACA). Participants for this study included former campers recruited from overnight and day camps that varied in affiliation, geographical area, and population served. Four of the camps served socio-economically diverse campers. Table 2 shows a breakdown of the sample stratification. The study participants were chosen via this stratified sampling strategy to get varied perspectives and interview responses, yet we realize that by interviewing future camp counselors, the sample is favorably biased toward camp.

The sample included 57 former campers who shared how their experiences at camp applied to academics and the workplace. Most participants had attended overnight summer camps as children for five weeks or more. Participants ranged in age from 16-23 years old; all 57 individuals had either previously or currently held non-camp jobs and discussed how camp lessons applied in the workplace. Fifty-five participants, including 25 who had been in college for at least one academic year, answered questions about how their summer camp experience contributed to their academic preparation. The sample included 44 females, 12 males, and 1 


\section{Role of Camps in Academic and Workplace Readiness}

individual who identified as gender non-conforming. The sample was disproportionally female; however, this trend is consistent with typical camp employment and camper enrollment (Wilson, 2017a). The sample was relatively homogeneous in terms of racial identity with 43 participants who identified as Caucasian. Additionally, individuals identified as multi-racial, African-American, and Hispanic. The 57 interview participants provided a variety of responses and the interviews reached saturation where minimal new information was discussed (Miles, Huberman, \& Saldana, 2014).

Table 2. Breakdown of Sample Stratification for the 22 ACA-Accredited Camps

\begin{tabular}{|l|l|l|l|}
\hline Type & Region & Affiliation & Population \\
\hline Overnight -10 & North-East -7 & Not for Profit -7 & Coed -19 \\
Day -5 & Central -5 & Agency -5 & Girls Only -2 \\
Both -7 & Eastern -5 & For Profit -4 & Boys Only -1 \\
& Western -5 & Religious -4 & \\
& & Medically-Focused -2 & \\
\hline
\end{tabular}

\section{Procedures}

Data collection involved structured interviews with open-ended questions designed to gain a deeper understanding of participants' learning outcomes from camp related to academic and workplace readiness and the mechanisms at camp that supported their learning. Interviews were conducted via phone and lasted approximately 25 minutes each. All former campers completed the necessary consent forms prior to being interviewed. To ensure the accuracy of the interviews, all phone calls were recorded. Representative questions included:

- What did you learn by being a camper?

- Have you had a paid job since your time at camp? If yes, do you think your camp experience has helped with this? If so, how?

- Have you attended a college or university? If yes, do you think your camp experience has helped with this? If so, how? If not, do you think your camp experience has helped with high school or to prepare you for college?

After outcomes were offered by the participants, a follow-up question was asked to link outcomes to mechanisms: 


\section{Role of Camps in Academic and Workplace Readiness}

- When you think back to your time as a camper, what about summer camp made this learning possible?

\section{Data Analysis}

Upon completion of the interviews, the audio recordings were transcribed, and these transcriptions were analyzed using constant comparison. Constant comparison "generates inductively conceptual codes and sub codes as well as relationship codes" (Bradley, Curry, \& Devers, 2007, p.1762). Learning outcomes and mechanisms were inductively coded into themes using open coding. Then, axial coding was used to link specific learning outcomes to mechanisms that supported former campers' learning (Marshall \& Rossman, 2011).

Interrater reliability was implemented to confirm the credibility and trustworthiness of the data. Interrater reliability involved creating definitions for each code and two coders independently applying the codes to the data (Vaismoradi, Turunen, \& Bondas, 2013). The raters then met to discuss any disagreements on the codes until a consensus was reached on the final codes. Interrater reliability was calculated based on percent agreement; consensus was reached by raters for $99 \%$ of the coded data. Our a priori reporting cutoff for codes was $5 \%$ frequency or greater with the understanding that outcomes might meet this criteria in one domain (e.g., work) yet fail to meet it in the other domain (e.g., academics) and that some mechanism codes might reach this criteria for some outcomes yet fail to meet it for others.

\section{Results}

The research questions sought to understand the outcomes former campers reported learning from their time at camp related to academic and workplace readiness, and the mechanisms at camp that promoted those learning outcomes.

\section{Academic and Workplace Readiness Outcomes}

Former campers' outcomes fall under three higher-order themes that align with the National Research Council's framework on clusters of skills that support academic and workplace readiness: teamwork and collaboration, positive core self-evaluations, and work ethic and conscientiousness. Within these clusters, the learning outcomes were coded into 10 subcategories that included relationship skills, teamwork, how to live with peers, emotion 
Journal of Youth Development | http://jyd.pitt.edu/ | Vol. 13 Issue 1-2 DOI 10.5195/jyd.2018.563

\section{Role of Camps in Academic and Workplace Readiness}

regulation, self-confidence, organization, responsibility, independence, perseverance, and career orientation. See Table 3 for an overview of the main identified outcomes.

Table 3. Outcomes Identified as Central to Academic and Workplace Readiness

\begin{tabular}{|c|c|c|c|c|}
\hline \multicolumn{2}{|c|}{$\begin{array}{l}\text { Skill } \\
\text { cluster }\end{array}$} & $\begin{array}{l}\text { Outcome } \\
\text { code }\end{array}$ & Definition & Illustrative quote \\
\hline \multirow{3}{*}{\multicolumn{2}{|c|}{ 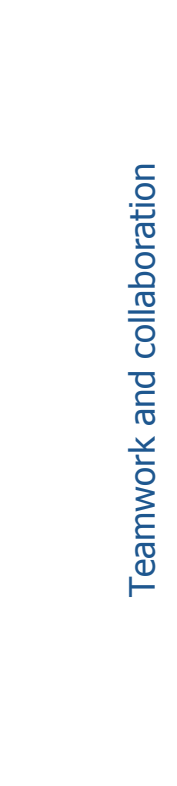 }} & $\begin{array}{l}\text { Relationship } \\
\text { skills }\end{array}$ & $\begin{array}{l}\text { Establish and } \\
\text { maintain } \\
\text { relationships }\end{array}$ & $\begin{array}{l}\text { Some people just don't like to take that first step, but at } \\
\text { camp, you talk to everyone and everyone wants to talk to } \\
\text { you. That definitely helps you make friends at school. }\end{array}$ \\
\hline & & Teamwork & $\begin{array}{l}\text { More effective } \\
\text { when working in } \\
\text { groups of peers } \\
\text { toward a } \\
\text { specified goal }\end{array}$ & $\begin{array}{l}\text { Learning to work on a team because at Starbucks } \\
\text { you'll have this specific job of making the drinks but } \\
\text { you have to rely on the person at the register and at } \\
\text { the drive-thru. It's really a team effort. }\end{array}$ \\
\hline & & $\begin{array}{l}\text { How to live } \\
\text { with peers }\end{array}$ & $\begin{array}{l}\text { How to live in } \\
\text { close quarters } \\
\text { with peers }\end{array}$ & $\begin{array}{l}\text { Well, the funny parallel with college is when you're } \\
\text { moving away and living again with your peers. Camp } \\
\text { helped when I had a roommate and when I was living } \\
\text { in a dorm. }\end{array}$ \\
\hline & \multirow{2}{*}{ 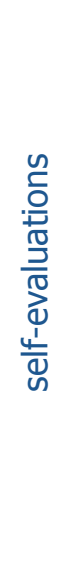 } & $\begin{array}{l}\text { Emotion } \\
\text { regulation }\end{array}$ & $\begin{array}{l}\text { Controlling } \\
\text { emotional } \\
\text { impulses when } \\
\text { unproductive }\end{array}$ & $\begin{array}{l}\text { The experiences at Camp X definitely applied to customer } \\
\text { service because you can't get mad at the customers. The } \\
\text { customer is always right and so you have to really find it } \\
\text { deep within yourself to not yell. }\end{array}$ \\
\hline & & $\begin{array}{l}\text { Self- } \\
\text { confidence }\end{array}$ & $\begin{array}{l}\text { Believe that they } \\
\text { can be } \\
\text { successful in the } \\
\text { things they do }\end{array}$ & $\begin{array}{l}\text { It just made me confident talking to adults or older people. } \\
\text { Going into the job I had never really talked to customers or } \\
\text { done anything before but it was super natural and I think I } \\
\text { can contribute [sic] that to a lot of confidence I gained at } \\
\text { camp. }\end{array}$ \\
\hline
\end{tabular}




\section{Role of Camps in Academic and Workplace Readiness}

Table 3. (continued)

\begin{tabular}{|c|c|c|c|}
\hline $\begin{array}{l}\text { Skill } \\
\text { cluster }\end{array}$ & $\begin{array}{l}\text { Outcome } \\
\text { code }\end{array}$ & Definition & Illustrative quote \\
\hline \multirow{5}{*}{ 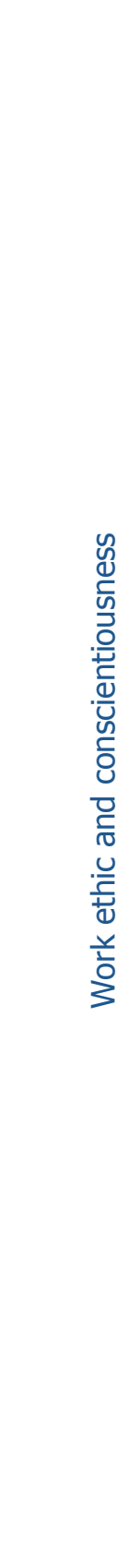 } & Organization & $\begin{array}{l}\text { Organization of } \\
\text { tasks, materials, } \\
\text { or people }\end{array}$ & $\begin{array}{l}\text { Being timely and organized, I got that from camp. Being } \\
\text { able to be on track and keep up with things that I need to } \\
\text { get done or just places I need to be that's always a big } \\
\text { thing in my everyday life that I've learned from camp that I } \\
\text { can use and in the job I had. }\end{array}$ \\
\hline & Responsibility & $\begin{array}{l}\text { Accountable for } \\
\text { own actions and } \\
\text { words }\end{array}$ & $\begin{array}{l}\text { At camp, you always had some sort of job or chore, and it } \\
\text { taught me a little bit more responsibility than I had before I } \\
\text { went. I was a waitress and a busgirl, so I had to clean up } \\
\text { and being at camp, you had to clean up your own mess. } \\
\text { That definitely helped with my job. }\end{array}$ \\
\hline & Independence & $\begin{array}{l}\text { Rely less on } \\
\text { adults and } \\
\text { others in day- } \\
\text { to-day activities }\end{array}$ & $\begin{array}{l}\text { I think that a big thing for me was learning to do things on } \\
\text { my own and not have to rely on my parents for that } \\
\text { week. Like washing my laundry throughout the week and } \\
\text { not being able to discuss what my day was like over dinner. } \\
\text { It's a good thing to be able to learn from camp to not totally } \\
\text { rely on your parents } 100 \% \text { of the time. }\end{array}$ \\
\hline & Perseverance & $\begin{array}{l}\text { Overcome } \\
\text { challenges } \\
\text { through } \\
\text { sustained effort }\end{array}$ & $\begin{array}{l}\text { There's a lot of heat and you're on your feet and you're } \\
\text { running around and there's a lot of things that you're } \\
\text { doing. And you can't give up because obviously you're } \\
\text { working there and you're being paid to do what you're } \\
\text { doing. }\end{array}$ \\
\hline & $\begin{array}{l}\text { Career } \\
\text { orientation }\end{array}$ & $\begin{array}{l}\text { Better } \\
\text { understanding } \\
\text { of college and } \\
\text { career options }\end{array}$ & $\begin{array}{l}\text { From camp, I got experience working with kids which } \\
\text { helped because I was a little nervous to be alone in the } \\
\text { classroom with a bunch of kids but camp definitely gave me } \\
\text { experience, so I knew that I would be able to handle it, and } \\
\text { I learned little tips [about working with kids]. }\end{array}$ \\
\hline
\end{tabular}




\section{Role of Camps in Academic and Workplace Readiness}

Some learning outcomes were applicable to both academics and the workplace, while others were related to one context or the other. Moreover, some learning outcomes were more salient than others to academic and workplace readiness. Figure 1 contains a heat map that provides the reader with a visual representation of the learning outcomes' relevance to academics and the workplace. Darker colors on the heat map indicate the learning outcome was more salient in either academics or work.

\section{Figure 1. Academic and Workplace Readiness Outcomes}

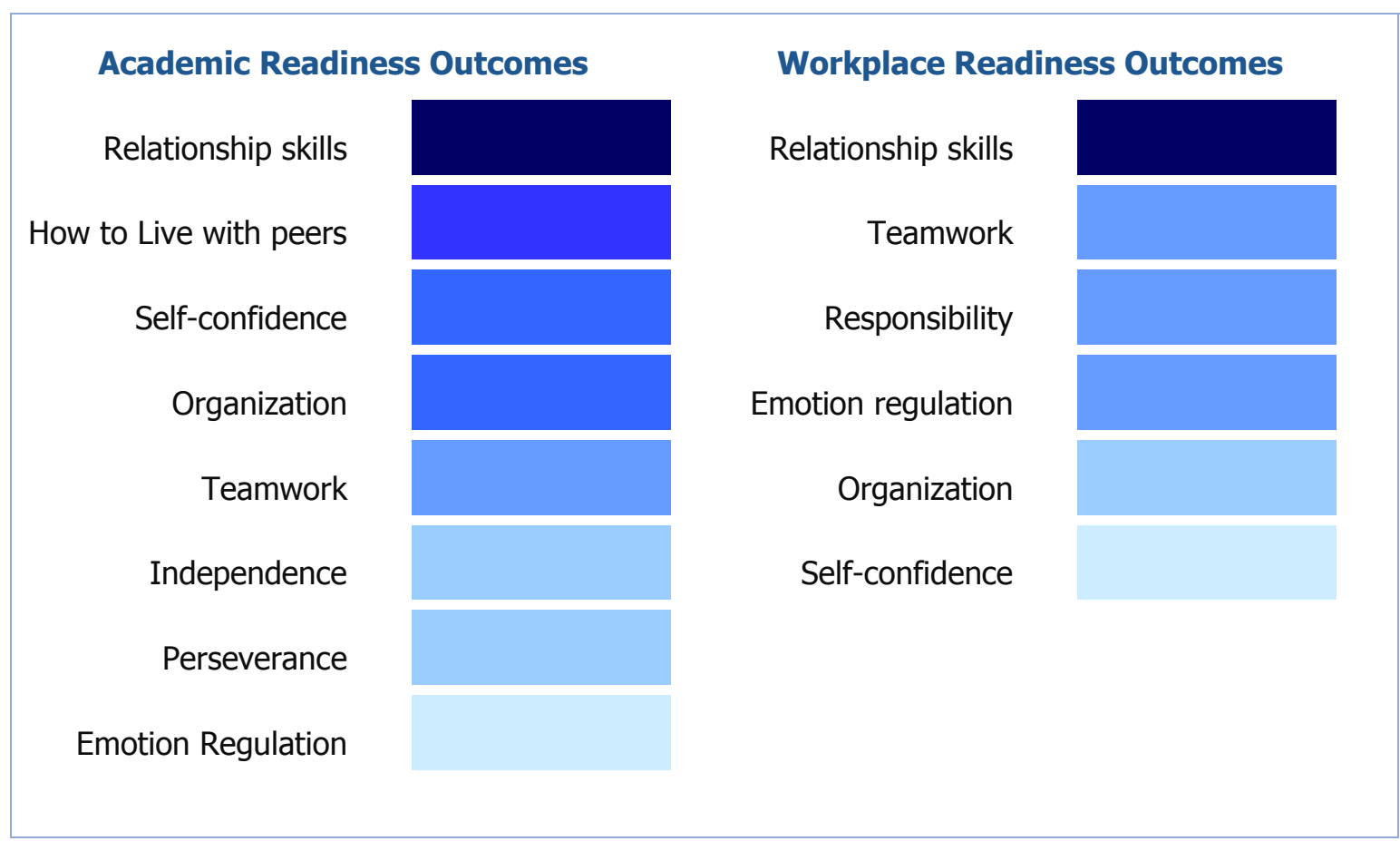

Note. Due to the complexity of the qualitative data, the authors have purposely chosen not to report frequencies or percentages. Furthermore, two academic outcomes (career orientation and working with kids) met our a priori cut off of $5 \%$, but we believe these outcomes are distinct to the sample and have chosen to include them in the narrative but not the heatmap.

\section{Teamwork and Collaboration}

Relationship skills was the most central theme interviewees found applicable to academic and workplace readiness. Almost half of participants thought the relationship skills learned at camp helped them reach out and make friends at school. Relationship skills were also beneficial for participants in their jobs; they felt it helped their ability to provide superior customer service at work. 
Teamwork was useful in academics; interviewees commonly referred to their coursework where working in groups was the norm. One individual pursuing an early childhood education degree stated, "I'm working with other people in my field on specific projects in the class. There's teambuilding skills I definitely learned at camp which helps that process." Teamwork was also relevant when working with colleagues in the various jobs participants had.

Many former campers said they learned how to live with peers at camp; this learning outcome was most frequent in participants who already attended some college. Learning how to live with peers at camp was useful when former campers lived in a dorm with a roommate at college.

\section{Positive Core Self Evaluations}

Participants indicated they learned emotion regulation, which helped in academics and their jobs. Former campers were better able to manage their emotions with difficult clients at work. One student used emotional regulation learned at camp to deal with issues of being discriminated against at college, "People have said some crazy things to my face but I had to take what they were saying. Instead of freaking out, I had to just respond in a calm manner and have an intentional conversation."

Confidence learned at camp helped former campers at school when talking to their teachers, "I'm not afraid to ask for help. If I have a question, I'm not scared to go to office hours or to a tutoring session." At work, participants developed the confidence to talk to older adults (e.g., bosses or customers) or complete an assigned task. One interviewee said, "Camp had an effect at my work helping instill in me a sense of confidence and getting done the task I have in front of me effectively."

\section{Work Ethic and Conscientiousness}

Camp helped individuals learn organization. In academics, participants felt they were able to better organize their time. Additionally, participants used organization learned from camp at work, "the organizational value is really important because we'll have so much paperwork from so many different cases [at work] and we need to make sure we're on top of that."

Former campers learned responsibility from attending camp, which was most useful in their jobs. One individual said, "For my cleaning job there's not a set schedule and I don't report to 
anyone. I kind of just go on my own and clean rooms. Camp taught me how to be responsible because people were always depending on you and the rest of your cabin was expecting you to show up to places on time."

Participants said camp helped them learn independence, which was useful in college. Generally, interviewees attending college were away from their parents for extended periods of time and camp gave them a setting to develop independence.

Attending camp helped former campers learn perseverance, which was useful in academics. One participant said she has clients as a part of her social work program who can be difficult, and she learned "perseverance with difficult clients."

Some former campers reported career orientation as a learning outcome gained from camp. Participants indicated they learned to work with kids during their time at camp, which was useful in their jobs. Moreover, former campers reflected on how camp affected their career, job, and college program choices. Individuals were interested in a variety of disciplines due to their time spent at camp, such as environmental sciences, nursing, and social work. One participant said, "I know the most useful thing I learned at summer camp impacting my college career is learning so much about the natural world and the importance of conservation because I'm now majoring in environmental science and education." It's important to note that these themes may be overrepresented in these data given the nature of our sampling strategy.

\section{Leadership and Intellectual Openness}

Outcomes associated with leadership and intellectual openness (cf., National Research Council, 2012) were mentioned by the participants but did not meet our a priori reporting cutoff. Codes for peer leadership and openness to new things were present in the data, yet neither code occurred with enough frequency to warrant inclusion as a formal theme related to academic and workplace readiness.

\section{Mechanisms of Learning}

The mechanisms at camp that supported campers' learning outcomes were predominantly experiential learning, camp as separate time and space, camp schedules, the role of counselors, communal living, safe and supportive environments, and diversity of people. Each mechanism supported participants' learning of specific academic and workplace readiness outcomes. Table 
Journal of Youth Development | http://jyd.pitt.edu/ | Vol. 13 Issue 1-2 DOI 10.5195/jyd.2018.563

Role of Camps in Academic and Workplace Readiness

4 gives an overview of the mechanisms identified during the coding process that were linked to specific learning outcomes.

Table 4. Key Mechanisms Linked to Academic and Workplace Readiness Outcomes

\begin{tabular}{|c|c|c|c|}
\hline $\begin{array}{l}\text { Mechanism } \\
\text { code }\end{array}$ & Definition & $\begin{array}{l}\text { (Outcome topic) Illustrative } \\
\text { quote }\end{array}$ & Linked to outcomes \\
\hline $\begin{array}{l}\text { Experiential } \\
\text { learning }\end{array}$ & Learned it by doing & $\begin{array}{l}\text { (Teamwork) We would do a lot of } \\
\text { the activities that you couldn't make } \\
\text { it through yourself. There was this } \\
\text { mini wall and you had to get over it } \\
\text { but you couldn't get over it unless } \\
\text { you helped push one person up. }\end{array}$ & $\begin{array}{l}\text { Relationship skills, } \\
\text { teamwork, how to live } \\
\text { with peers, organization, } \\
\text { responsibility, } \\
\text { independence, } \\
\text { perseverance, career } \\
\text { orientation, emotion } \\
\text { regulation, and self- } \\
\text { confidence }\end{array}$ \\
\hline $\begin{array}{l}\text { Separate time } \\
\text { and space }\end{array}$ & $\begin{array}{l}\text { Camp as a space that } \\
\text { is separated in time } \\
\text { and space from "life" }\end{array}$ & $\begin{array}{l}\text { (Independence) At camp, I was able } \\
\text { to realize that I will be okay } \\
\text { independent from my family without } \\
\text { my parents' necessarily holding my } \\
\text { hand every step of the way. }\end{array}$ & $\begin{array}{l}\text { Relationship skills, how } \\
\text { to live with peers, } \\
\text { organization, } \\
\text { responsibility, and } \\
\text { independence }\end{array}$ \\
\hline $\begin{array}{l}\text { Camp } \\
\text { schedule }\end{array}$ & $\begin{array}{l}\text { Structure of camp } \\
\text { activities and flow }\end{array}$ & $\begin{array}{l}\text { (Organization) [At camp] the } \\
\text { schedule is broken down for } \\
\text { everything you do. There's a lot to } \\
\text { do at college. I have class at 8:00, } \\
\text { get up at 7:00, do homework, } \\
\text { making sure I'm prioritizing time for } \\
\text { friends, for school, for everything. I } \\
\text { feel like Camp X really helped teach } \\
\text { us organization. }\end{array}$ & $\begin{array}{l}\text { Organization, } \\
\text { responsibility, } \\
\text { independence, } \\
\text { perseverance, and } \\
\text { emotion regulation }\end{array}$ \\
\hline
\end{tabular}


Table 4. (continued)

\begin{tabular}{|c|c|c|c|}
\hline $\begin{array}{l}\text { Mechanism } \\
\text { code }\end{array}$ & Definition & $\begin{array}{l}\text { (Outcome topic) Illustrative } \\
\text { quote }\end{array}$ & Linked to outcomes \\
\hline Counselors & $\begin{array}{l}\text { Camp staff as near } \\
\text { peer role models, } \\
\text { caring and } \\
\text { compassionate } \\
\text { adults, and } \\
\text { facilitators/teachers }\end{array}$ & $\begin{array}{l}\text { (Relationship skills) The counselors } \\
\text { lead by example for sure. You never } \\
\text { saw a counselor walk by another } \\
\text { counselor and not say hi. }\end{array}$ & $\begin{array}{l}\text { Relationship skills, } \\
\text { career orientation, } \\
\text { emotion regulation, and } \\
\text { self-confidence }\end{array}$ \\
\hline $\begin{array}{l}\text { Communal } \\
\text { living }\end{array}$ & $\begin{array}{l}\text { Living in a confined } \\
\text { space with a group of } \\
\text { peers }\end{array}$ & $\begin{array}{l}\text { (Relationship skills) When you have } \\
15 \text { girls living in one room you don't } \\
\text { really have a choice but to all get } \\
\text { along and build relationships. }\end{array}$ & $\begin{array}{l}\text { Relationship skills, how } \\
\text { to live with peers, } \\
\text { responsibility, } \\
\text { independence, and } \\
\text { emotion regulation }\end{array}$ \\
\hline $\begin{array}{l}\text { Safe and } \\
\text { supportive } \\
\text { environment }\end{array}$ & $\begin{array}{l}\text { Safe space to be } \\
\text { yourself, feel } \\
\text { accepted/respected, } \\
\text { and try new things }\end{array}$ & $\begin{array}{l}\text { (Independence) Camp gave me an } \\
\text { environment where it was okay to } \\
\text { make mistakes and I think I would } \\
\text { have had to learn independence in } \\
\text { an environment where it was less } \\
\text { okay to make mistakes in the future } \\
\text { if I hadn't gone to camp. }\end{array}$ & $\begin{array}{l}\text { Relationship skills, } \\
\text { independence, and self- } \\
\text { confidence }\end{array}$ \\
\hline $\begin{array}{l}\text { Diversity of } \\
\text { people }\end{array}$ & $\begin{array}{l}\text { Beyond superficial } \\
\text { interactions with } \\
\text { people who are } \\
\text { qualitatively different }\end{array}$ & $\begin{array}{l}\text { (Relationship skills) Our staff were } \\
\text { from } 11 \text { or } 12 \text { different countries. } \\
\text { We had campers from so many } \\
\text { different backgrounds. }\end{array}$ & Relationship skills \\
\hline
\end{tabular}

\section{Experiential Learning}

Opportunities for experiential learning or "learning by doing" was one of the most universal mechanisms for a variety of outcomes. Commonly campers are placed in situations where they can practice making friends and working collaboratively as a team (e.g., in cabins, while doing activities, and during unstructured time). Experiential learning involved campers being challenged and struggling to complete a task; campers learned to manage emotions, persevere, 


\section{Role of Camps in Academic and Workplace Readiness}

and overcome challenges because of these experiences. Successful completion of tasks helped campers have self-confidence in their ability to succeed in other aspects of life.

\section{Separate Time and Space}

Study participants directly attributed learning to the separation between camp (mostly related to overnight camps) and parents, family, friends, and school. For example, campers had to make decisions without involving parents or could not rely on communication with pre-existing friends. This fact often pushed campers to make new friends and become more independent and responsible. In addition, former campers spoke about the break from technology as a benefit. The lack of access to phones, computers, and social media forced them to build faceto-face relationships as opposed to having their relationships mediated by technological interactions.

\section{Camp Schedules}

Many camps have an activity schedule and program flow in place that campers follow throughout the day. Campers are often responsible for waking up early, getting ready, following the schedule on their own, and ensuring they effectively organize their time so they can attend activities as expected. Camp timetables, schedules, and programming logistics can lead to long days filled with frequent activities which can be tiring; campers learned to manage their emotions and persevere through the busy days.

\section{Counselors}

Counselors were powerful levers of youth development; they were caring and compassionate individuals, teachers and facilitators, and role models. At times, counselors would provide support during emotional situations at camp and give advice on how to cope and manage emotions. Other times, counselors were identified as teachers and facilitators, impelling campers to engage in camp activities, which helped them learn specific skills. Occasionally, counselors or camp staff would teach campers certain topics (e.g., medical content) that influenced campers to explore jobs in that field. Finally, they were identified as near-peer role models whom campers looked up to and emulated. 


\section{Communal Living}

Communal living afforded campers the opportunity to live with people they had just met. This experience taught campers how to interact with peers, practice living with people other than their family, to be responsible for their daily living, and how to manage their emotions during disagreements with cabin mates.

\section{Safe and Supportive Environments}

Former campers believed camp had a safe and supportive culture that was maintained by peers, older campers, and counselors. Individuals' communication, actions, and behaviors cultivated an intangible atmosphere of safety and security. Camp, essentially, was a "bubble" where former campers felt comfortable being away from their parents for extended periods of time. Camp was a safe space where participants could practice their relationship skills and try new activities that fostered confidence in future interactions or tasks outside of camp.

\section{Diversity of People}

Campers can be diverse and vary across a multitude of factors such as values, beliefs, family structure, gender identity, interests, personality, hometown, socioeconomic status, and race. A broad array of individuals at camp helped participants learn how to interact with people different from themselves.

\section{Discussion}

The primary purpose of this study was to understand what former campers believe they learned during their time at camp related to academic and workplace readiness. When camp impacts young peoples' lives, campers can learn a multitude of skills that support academic and workplace readiness such as teamwork and collaboration (relationship skills, teamwork, and how to live with peers), positive core self-evaluation (emotion regulation and self-confidence), and work ethic and conscientiousness (organization, responsibility, independence, perseverance, and career orientation).

\section{Academic and Workplace Readiness Outcomes}

The "skills gap" occurring among young people in the United States is disconcerting. Policy makers and educators with an invested interest in identifying ways for young people to develop 
skills so they are prepared for academics and the workplace may want to utilize summer camps as a viable and vibrant developmental context. This study supports the premise that summer camps can be a worthwhile option to help youth develop essential skills necessary to be prepared for school and the workplace.

Former campers overwhelmingly mentioned the role of camp in developing teamwork and collaboration skills. The social nature of camp continues to be a strength. Employers regularly identify social competencies as the "most valuable yet hard-to-find" capabilities of workers (e.g. Casner-Lotto \& Barrington, 2006). The idea that summer camp helps individuals develop social skills is not new; this study provides evidence that social skills are learned at camp and may be transferred to academics and the workplace at least a year after the program ends. While support for teamwork and collaboration was greatest in these data, aspects of positive selfevaluations, and work ethic and conscientiousness were also attributed to camp and remain in high demand in academics and the workplace.

As expected, former campers did not attribute some academic and workplace readiness skills to camp. Outcomes such as cognitive processes and strategies (e.g., problem solving), knowledge (e.g., information literacy), and creativity (e.g., innovation) were not generally attributed to summer camp participation in these data. As stated in the results section, leadership and intellectual openness were mentioned by some study participants as attributable to camps and as useful in academics and the workplace yet were less common and did not warrant inclusion in this paper as specific themes. Previous research positions camp programs as complementary to academic learning in developing competencies such as problem solving, creativity, and information literacy in youth (Gordon, Bridglall, \& Meroe, 2005). Although we did find direct support for some of these outcomes, problem solving and creativity were infrequently mentioned specifically in the interviews. However, most of the examples of experiential learning as a mechanism did center on the necessity of solving a problem. Thus, while campers do solve problems at summer camps and use creativity, we cannot offer any definitive evidence that camp enhances these skills.

\section{Leveraging Mechanisms in Context}

Summer camp is a context that can incorporate intentional programming to elicit learning outcomes related to academic and workplace readiness. In order to effectively target specific outcomes, camp programmers and frontline staff must be aware of the mechanisms at camp that help facilitate campers' learning. 
Camps are rich mediums for high quality experiential learning (e.g., Bialeschki, Fine, \& Bennett, 2016). It was clear through the interviews that the former campers learned a variety of lessons through physical, emotional, and cognitive engagement necessitated by application and practice. The direct experiences were often inherent in the camp programs and resulted in learning the identified academic and work-related outcomes. Camp programmers and staff should keep this in mind when designing and implementing programs. Youth learn in a variety of ways, but camp professionals should continue to de-prioritize lessons that do not involve application and practice despite pushes for academic accountability.

The separation innate in the camp experience remains both a strength and a weakness. Youth programs often seek to connect their programming with local communities and families; this connection is recognized as an important aspect of high quality youth programming (e.g., Eccles \& Gootman, 2002). Despite this notion, the separation of camp from local communities facilitates growth in ways that are distinct from integration. Camp professionals should continue to understand the merits of the remote nature of many camps (Garst et al., 2011; Johnson, Goldman, Garey, Britner, \& Weaver, 2011) and the "bans" on phones and electronics. If camps move toward integrating communities, families, and electronics into camp, they should understand that, even in the minds of youth, benefits exist to having access to a space unfettered by the volume and variety of outside noise.

High quality counselors and frontline staff remain the essential ingredient to a successful camp program, and although this idea is widely understood, recruiting, training, and retaining high quality staff in these low-paid, seasonal positions remains a top challenge for camps (Wilson, 2017b). While this study provides little insight into how camps should proactively address this issue, our findings do reiterate the critical roles camp staff play in youth development.

Communal living, a hallmark of overnight camps, is another camp mechanism that is distinct from many other youth programs. Living with a group of peers in a confined space for a week or more offers a clear parallel to most college housing options and necessitates dialog and communication among peers. Even for camps that do not have communal living quarters, camp professionals should embrace lived-experiences that authentically require youth to navigate shared spaces and manage interpersonal conflicts. While these lessons might be directly applicable to common living arrangements as young adults leave home, communal living also provides an authentic practice platform for innumerable interpersonal interactions, which are useful across the lifespan. 
Camp professionals and camp staff have worked diligently to create cultures of safety and support. This culture remains critical to the learning potential of summer camps (Henderson, Whitaker, Bialeschki, Scanlin, \& Thurber, 2007). Camp professionals should continue to prioritize hiring counselors who culturally fit with their camps, continue to attend to favorable adult/camper ratios and adults' presence, and continue to carefully tend to the culture and feel of their camps. Likewise, counselors should attend to a healthy and productive culture of safety and support; it is this culture, and these interpersonal interactions, that allow campers the space to experiment, fail, and persevere.

In addition to staff, campers learn a great deal from each other. Diversity of the other campers was commonly linked with learning about relationship skills. While aspects of racial, ethnic, and gender diversity did surface, many of the former campers pointed to a diversity of beliefs, values, abilities, and social class, and being in close contact with individuals beyond the campers' normal social circles as important. Many camps struggle to recruit diverse campers and staff (Wilson, 2017b). Though this study does not provide a concrete strategy to address this issue, there is support that diversity of people at camp affords campers the opportunity to interact with individuals different from themselves.

\section{Limitations}

The primary limitation of this study involves the sample. The purpose of the intentionally stratified sampling strategy was to recruit individuals who could speak to a broad cross-section of experiences at organized summer camps. While the strength of this sample allows a variation in camp affiliations, geographic regions, and camp program offerings, the disproportionate number of white, female participants who attended overnight camp and subsequently applied for camp employment skewed the overall sample. Two of the themes (working with kids and career orientation) may be overrepresented in these data given our sampling strategy. Additionally, the sample was likely skewed toward overnight camps because campers were asked to reflect on their meaningful camp experiences and overnight camps typically engage campers in sustained experiences that may be particularly influential on youth development outcomes (Garst et al., 2011). Furthermore, the sample may have been skewed toward white, female participants because these demographics generally reflect the trends for counselors hired and those that attend camp (Wilson, 2017a). 


\section{Role of Camps in Academic and Workplace Readiness}

The inherent bias in this sample is clear. However, the research provides valuable insight from engaged former campers who could identify the most promising impacts of the camp experience applicable to academic and workplace readiness. This process of inductively substantiating promising outcomes of camp remains critical to advancing further understanding of the impacts of summer camp on youth and informing subsequent work. The biased nature of the sample does warrant further efforts to support these findings. A less biased national sample is being employed in the next phase of our work. Finally, the study used memories to recall former campers' experiences and the accuracy of these summer camp experiences may have been affected as a result (Garst, Williams, \& Roggenbuck, 2010).

\section{Directions for Future Research}

This study identified some key learning outcomes from camp that may contribute to academic and workplace readiness. Future research should focus on improving the representativeness of the sample, transitioning from a solely retrospective study design, and adding quantitative measures to augment the qualitative data. Stronger sampling frames could include individuals not currently linked to the camp community, study participants who have completed years of college, or former campers who have well-established careers. A larger sample might also allow comparisons across types of camps and campers. Following actual campers across multiple years in a longitudinal study would eliminate the overreliance on retrospective memory recall. Identifying the most promising outcomes and measuring them over time would allow for the addition of quantitative data.

In addition to continuing work on outcomes aligned with academic and workplace readiness, the nature of camp should be further studied. While better understanding the qualities of the camp experience that most facilitate outcomes is worthwhile, summer camp should be directly compared to alternative contexts such as school, work, or sports. Such future research will better allow the profession of organized camping to articulate why summer camps fill a niche in broader youth programming efforts and how camps most effectively function.

\section{Conclusion}

This research identified key learning outcomes former campers believed were learned at camp that may be applicable to academic and workplace readiness. Consistent with the outcomebased literature, summer camps seem well-suited to teach relationship skills, teamwork, how to 


\section{Role of Camps in Academic and Workplace Readiness}

live with peers, self-confidence, organization, responsibility, independence, perseverance, career orientation, and emotion regulation. The mechanisms at camp that help support campers' learning of these outcomes include experiential learning, camp as separate in time and space, camp schedules, counselors, communal living, safe and supportive environments, and diversity of people. Understanding how outcomes are fostered in a camp setting remains important. Some learning outcomes are implicitly learned via mechanisms inherent to camp programs (e.g. communal living at overnight camps). Other mechanisms can be more intentionally used to elicit intended learning outcomes, such as experiential learning. Determining how to intentionally program for specific outcomes related to academic and workplace readiness can best be addressed by individual camps. Concerted efforts can be made by camp staff to intentionally program via the mechanisms that help facilitate the most pertinent learning outcomes. With additional effort dedicated to intentional programming, summer camp may bolster its role in preparing youth with the skills necessary to succeed in academics and the workplace.

\section{Acknowledgments}

This study was made possible through support from the American Camp Association. In addition, ReAC (the American Camp Association's Research Advisory Committee) provided valuable feedback and insights throughout the study. Dr. Laurie Browne, the American Camp Association Director of Research, was extremely helpful in camp recruitment and connected us to camps and camp directors. We would also like to acknowledge the camp directors and staff who helped recruit former campers to participate in the study. To the former campers we interviewed, thank you for sharing what you learned from your camp experiences. Thank you to Drs. Doug Hacker and Kevin Rathunde for your expertise and advice. Lastly, thank you to Lisa Meerts-Brandsma for your help conducting the interviews.

\section{References}

American Camp Association. (2005). Directions: Youth development outcomes of the camp experience. Martinsville, IN: American Camp Association, 1-24.

Bialeschki, M. D., Fine, S. M., \& Bennett, T. (2016). The camp experience, learning through the outdoors. In B. Humberstone, H. Prince, \& K. Henderson (Eds.), Routledge International Handbook of Outdoor Studies, (p. 227-235). New York, NY: Routledge. 
Journal of Youth Development | http://jyd.pitt.edu/ | Vol. 13 Issue 1-2 DOI 10.5195/jyd.2018.563

Role of Camps in Academic and Workplace Readiness

Bradley, E. H., Curry, L. A., \& Devers, K. J. (2007). Qualitative data analysis for health services research: developing taxonomy, themes, and theory. Health Services Research, 42(4), 1758-1772.

Casner-Lotto, J., \& Barrington, L. (2006). Are they really ready to work? Employers' perspectives on the basic knowledge and applied skills of new entrants to the $21^{\text {st }}$ century US workforce. The Conference Board, Inc., Partnership for $21^{\text {st }}$ Century Skills, Corporate Voices for Working Families, and the Society for Human Resource Management.

Cochran, G. R., \& Ferrari, T. M. (2009). Preparing youth for the $21^{\text {st }}$ century knowledge economy: Youth programs and workforce preparation. Afterschool Matters, 8, 11-25.

Collins, L. (2006). The meaning of camp and social group work principles. Social Work with Groups, $29(2 \& 3), 133-148$.

Eccles, J., \& Gootman, J. A. (2002). Community programs to promote youth development. Washington, DC: National Academy Press.

Garst, B. A. (2010). From what to how: Targeting specific factors that influence outcomes. Journal of Extension, 48(6).

Garst, B. A., Browne, L. P., \& Bialeschki, M. D. (2011). Youth development and the camp experience. New Directions for Student Leadership, 2011(130), 73-87.

Garst, B. A., Williams, D., \& Roggenbuck, J. (2010). Exploring early $21^{\text {st }}$ century developed forest camping experiences and meanings. Leisure Sciences, 32, 90-107.

Gordon, E. W., Bridglall, B. L., \& Meroe, A. S. (2005). Supplementary education: The hidden curriculum of high academic achievement. Landham, MD: Rowman \& Littlefield.

Henderson, K. A., Whitaker, L. S., Bialeschki, M. D., Scanlin, M. M., \& Thurber, C. (2007). Summer camp experiences: Parental perceptions of youth development outcomes. Journal of Family Issues, 28(8), 987-1007.

Johnson, S. K., Goldman, J. A., Garey, A. I., Britner, P. A., \& Weaver, S. E. (2011). Emerging adults' identity exploration: Illustrations from inside the "camp bubble". Journal of Adolescent Research, 26(2), 258-295.

Manpower. (2010). Supply/demand: 2010 talent shortage survey results. Retrieved from https://candidate.manpower.com/wps/wcm/connect/3b781500428d4a12a0b8ee4f3871948a/2010 _global_Shortage_\%20Survey_results_0504101+def.pdf?MoD=AJPErES

Marshall, C., \& Rossman, G. B. (2011). Designing qualitative research. Thousand Oaks, CA: SAGE.

McClarty, K. L., Mattern, K. D., \& Gaertner, M. N. (Eds.). (2017). Preparing students for college and careers: Theory, measurement, and educational practice. New York, NY: Routledge.

Miles, M. B., Huberman, A. M., \& Saldana, J. (2014). Qualitative data analysis: A methods sourcebook (3 ${ }^{\text {rd }}$ ed.). Thousand Oaks, CA: SAGE.

NAEP. (2013). What is academic preparedness, and what are the provisional estimates? Retrieved from http://www.fldoe.org/core/fileparse.php/7667/urlt/0067577-wapwpe.pdf 
Journal of Youth Development | http://jyd.pitt.edu/ | Vol. 13 Issue 1-2 DOI 10.5195/jyd.2018.563

Role of Camps in Academic and Workplace Readiness

National Research Council. (2012). Education for life and work: Developing transferable knowledge and skills in the $21^{\text {st }}$ century. Washington, DC: National Academies Press. doi: 10.17226/13398

Sambolt, M., \& Blumenthal, D. (2013). Promoting college and career readiness: A pocket guide for state and district leaders. Washington DC: American Institutes for Research.

Thurber, C., Scanlin, M., Schueler, L., \& Henderson, K. (2007). Youth development outcomes of the camp experience: Evidence for multidimensional growth. Journal of Youth Adolescence, 36, 241-254.

Vaismoradi, M., Turunen, H., \& Bondas, T. (2013). Content analysis and thematic analysis: Implications for conducting a qualitative descriptive study. Nursing \& Health Sciences, 15(3), 398-405.

Venezia, A., \& Jaeger, L. (2013). Transitions from high school to college. The Future of Children, 23(1), 117-136.

Wilson, C. (2017a, March/April). 2016 Camper enrollment: With strong enrollment comes new challenges. Camping Magazine, 34-35.

Wilson, C. (2017b, September/October). Seven emerging issues today's camps face. Camping Magazine, 64-67.

Yohalem, N., \& Wilson-Ahlstrom, A. (2010). Inside the black box: Assessing and improving quality in youth programs. American Journal of Community Psychology, 45(3-4), 350-357. 